UDC 681.515: 519.7: 62-52

${ }^{1}$ Dr.Sc., Associate professor, Head of Security information and telecommunications department, National Mining University, Dnipro,

\title{
ADAPTIVE OPTIMAL CONTROL SYSTEM OF ORE LARGE CRUSHING PROCESS
}

Context. The task of efficiency increase of power-hungry ore large crushing process by creation of optimal control system of it is decided.

Objective is a improvement of control quality of ore large crushing process in conditions of information uncertainty about its state by synthesis of optimal control based on identification of the process predictive model during control system functioning.

Method. It is developed the adaptive optimal control system of the ore large crushing process, which realizes the following procedures: estimation of the controlled process state, its structural-parametric identification, prediction of the process progress, as well as synthesis of optimal control. The solution of problem of synthesis of large crushing process optimal control is carried out during system functioning by the principle of minimum of the generalized work on the sliding optimization interval with attraction of information about controlled process state to the new interval of optimization and its future state by the predictive model that allows to simplify the solution of problem of synthesis for nonlinear large crushing process and to compensate disturbances. The large crushing process identification is carried out by definition of the operating mode and dimension of its state, based on which it is performed the model structure and parameters with the help of composition of methods of global and local optimization that allows to increase the model accuracy.

Results. It is determined that for large crushing process the offered optimal control with prediction provides the decrease of the control error in $\sim 2$ times and increase of productivity of the process of ore self-grinding, the next one in the technological line, (due to stabilization of content of class $+100 \mathrm{~mm}$ in its input ore) on $3.8 \%$.

Conclusions. The scientific novelty of the work consists in development of adaptive system of large crushing process optimal control, in which the optimal control is formed in the course of functioning of control system by the principle of minimum of generalized work with the current estimation of the state of operated process and its future state by the predictive model that provides the control system invariance to the changes of operating modes of the equipment and the disturbing environment, and therefore, the improvement of control quality.

The practical significance of results of the work consists in development of algorithms of the current estimation and prediction of large crushing process state, its identification and synthesis of optimal control realizing control system.

Keywords: ore large crushing, control system, optimal control, identification, prediction.

\section{INTRODUCTION}

The development of technology of iron ores selfgrinding is caused by reduction of capital expenditure in view of use only of one stage of crushing - large crushing process (LCP), but at the same time, the specific expenses of the electric power were significantly increased. Therefore, it is important to increase the efficiency of LCP, for example, by creation of control system (CS) of it.

The crushing processes from the positions of control are difficult controlled objects (CO) characterized by nonlinearity of dependences, stochasticity of disturbances, nonstationarity and considerable transport delays [1, 2].

It causes the need to use universal and effective control principles of them according to the accepted criteria of quality. It is performed by means of optimal control, regarding which the one of the universal and effective in the practical application to complex nonlinear $\mathrm{CO}$ is the principle of minimum of the generalized work, which is implemented, for example, using the method with predictive model and functional of the generalized work (FGW) [3, 4]. Besides, $\mathrm{CO}$ nonstationarity assumes using in CS of algorithms of model adaptation and control laws to the real operating conditions of $\mathrm{CO}$.

The object of researches - the methods of control of technological cycles of ores crushing. The subject of researches - the methods of creation of optimal control systems of ores LCP. The purpose of the study is the improvement of control quality of ores LCP in conditions of uncertainty of information about its state by synthesis of optimal control based on identification of the process predictive model during CS functioning.

\section{PROBLEM STATEMENT}

Let the predicting $\mathrm{CO}$ model has the following form:

$$
\widehat{x}[k+n]=F\{x[k], u[k], w[k], \xi[k], a[k], k\},
$$

where estimation of its state $\hat{z}[k] \in\{x[k], u[k], w[k]\}$ is formed by means of the corresponding filters of observation, and the forecast of output coordinates serves for compensation of pure time delay and time for synthesis and realization of control.

The problem of synthesis of optimal control consists in finding of the operating influences $u_{\text {opt }}$, minimizing the control functional:

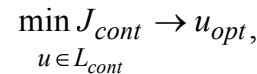

when observing the limitations for control $L_{\text {cont }}$.

At the same time, the formation of vector $I=\{F, a\}$ of estimation of structure $F$ (structural identification) and parameters $a$ (parametrical identification) of the $\mathrm{CO}$ model 
(1) is carried out based on vectors of signals of observation $\widehat{z}[k]$ by minimization of identification criterion:

$$
\underset{I \in L_{\text {ident }}}{\min J_{\text {ident }}} \rightarrow I_{\text {opt }}=\left\{F_{\text {opt }}, a_{\text {opt }}\right\}
$$

when observing the limitations $L_{\text {ident }}$.

\section{REVIEW OF THE LITERATURE}

One of the leading concepts of the modern control theory consists in achievement of the main ultimate goal at each stage of system functioning. It supposes use of CO models and it is provided by its optimization in real time [3]: $\mathrm{CO}$;

- optimal estimation (filtration) of dynamic processes in

- CO identification (estimation of structure and parameters of a model);

- synthesis of optimal control at each stage of system functioning;

- adaptation (adjustment of optimal control with incomplete information).

The application of method of analytical design of optimal controllers (ADOC) of Letov-Kalman for nonlinear CO leads a problem of synthesis to search of solution of the nonlinear differential equation that causes essential difficulties.

The development of the ADOC theory is the principle of minimum of the generalized work developed by the academician A.A. Krasovsky, according to whom the optimization of control is carried out by FGW. At the same time, the main functional equation is linear and has essentially simpler decisions [3-5].

The CS, realizing this method, use the adaptive optimal algorithms based on automatic identification of $\mathrm{CO}$ by means of the adaptive predictive model that allows to compensate nonstationarity of $\mathrm{CO}[6]$.

The synthesized model, which correctly transfers the dynamics of one mode of CO functioning, may be inadequate to the description of other mode. Therefore, it is needed the realization of adaptive structural-parametrical identification of $\mathrm{CO}$ in the course of CS functioning.

The process of structural-parametrical identification includes operations of structure determination, assessment, and optimization of parameters of the CO model $[5,7]$. The first two operations are solved by generation (by means of basis functions) of applicant models of different complexity and adjustment of their parameters with the subsequent selection of the best of them by the chosen criteria (result optimal structure). Operation of determination of optimal parameters is solved by methods of parametrical optimization by specification of the values of parameters received earlier on criteria of regularity on all selection of basic data (result optimal model).

At that, the urgent problems are the choice of basis functions, in terms of which it is carried out the identification, the choice of way of generation and selection of structures of different complexity (the method of structural optimization), as well as the choice of method of parametrical optimization and effective criteria of selection and optimization.
Traditionally the polynomials of Legendre, KolmogorovGabor, etc. are used for approximation of basis functions [8, 9]. The coefficients of these polynomials form the unknown parameters, the values of which are chosen to answer to observed temporary realization in the best way. The more productive is the use of neural networks (NN) and hybrid $\mathrm{NN}$ with fuzzy logic, which are universal and effective approximators $[9,10]$.

\section{MATERIALS AND METHODS}

Ore LCP is realized in conical crushers (fig. 1). Ore from the open pit is delivered by dump trucks or self-dumping cars (dumpcars). The crushed ore enters the conveyors 2, which supply the ore to bunkers of technological sections of self-crushing, via the bunker 1 under the crusher with the help of apron feeders.

The CS switches on the device 3 of the width control of the crusher opening, the converter 4 of the consumed active power of the crusher driving engine, the device 5 of control of the input ore fineness and rigidity, conveyor scales 6 , granulometer 7 , and actuating mechanism 8 of width regulation of the crusher opening 9 . The devices are connected with the controlling system of dataway 10 .

The output variables for LCP are: granulometric composition (GC) of the crushed product $\gamma_{\text {out }}$, the process productivity $Q_{c r}$ and power consumption $P_{c r}$; the control action is the size of the crusher opening $G$, and GC of the input ore $\gamma_{\text {in }}$ and its rigidity $S$ are referred to disturbances. Then, according to (1):

$$
x \in\left\{\gamma_{\text {out }}, Q_{c r}, P_{c r}\right\} ; u=\{G\} \text { and } w \in\left\{\gamma_{\text {in }}, S\right\} .
$$

At the ore mining and processing enterprises on magnetite quartzite processing, it is rational to carry out the control of LCP by qualitative index, for example, by minimization of difference between the current and given GC of the crushing product:

$$
J_{L C}=\left\|\gamma_{\text {out }}-\gamma_{\text {out }}^{\text {task }}\right\| \rightarrow \min ,
$$

when $P_{c r} \leq P_{c r \max }$ and $Q_{c r} \geq Q_{c r \text { min. }}$. Here $\gamma_{\text {out }}^{\text {task }}$ corresponds to the maximum productivity by the input ore of the self-crushing process, the following one in the technological line.

According to algorithm of work, the controlling system performs the estimation of the LCP current state to the time of beginning of the current interval of control and identification of its predictive model. By estimation of state and prediction of LCP it is determined the optimal control $G_{\text {opt }}$ for the following interval, which is worked by hydraulic system 8 .

According to (1) and (4), the predictive model of LCP becomes:

$$
\widehat{\gamma}_{\text {out }}[k+n]=F_{\widehat{\gamma}}\left\{\gamma_{\text {out }}[k], G[k], \gamma_{\text {in }}[k], S[k], \xi[k], a_{\widehat{\gamma}}[k], k\right\},
$$

where $F_{\widehat{\gamma}} \subset F$ and $a_{\hat{\gamma}} \subset a$.

The formation of vector is the result of estimation of LCP state:

$$
\widehat{z}=\left\{G, \gamma_{\text {in }}, S, \gamma_{\text {out }}, Q_{c r}, P_{c r}\right\}
$$




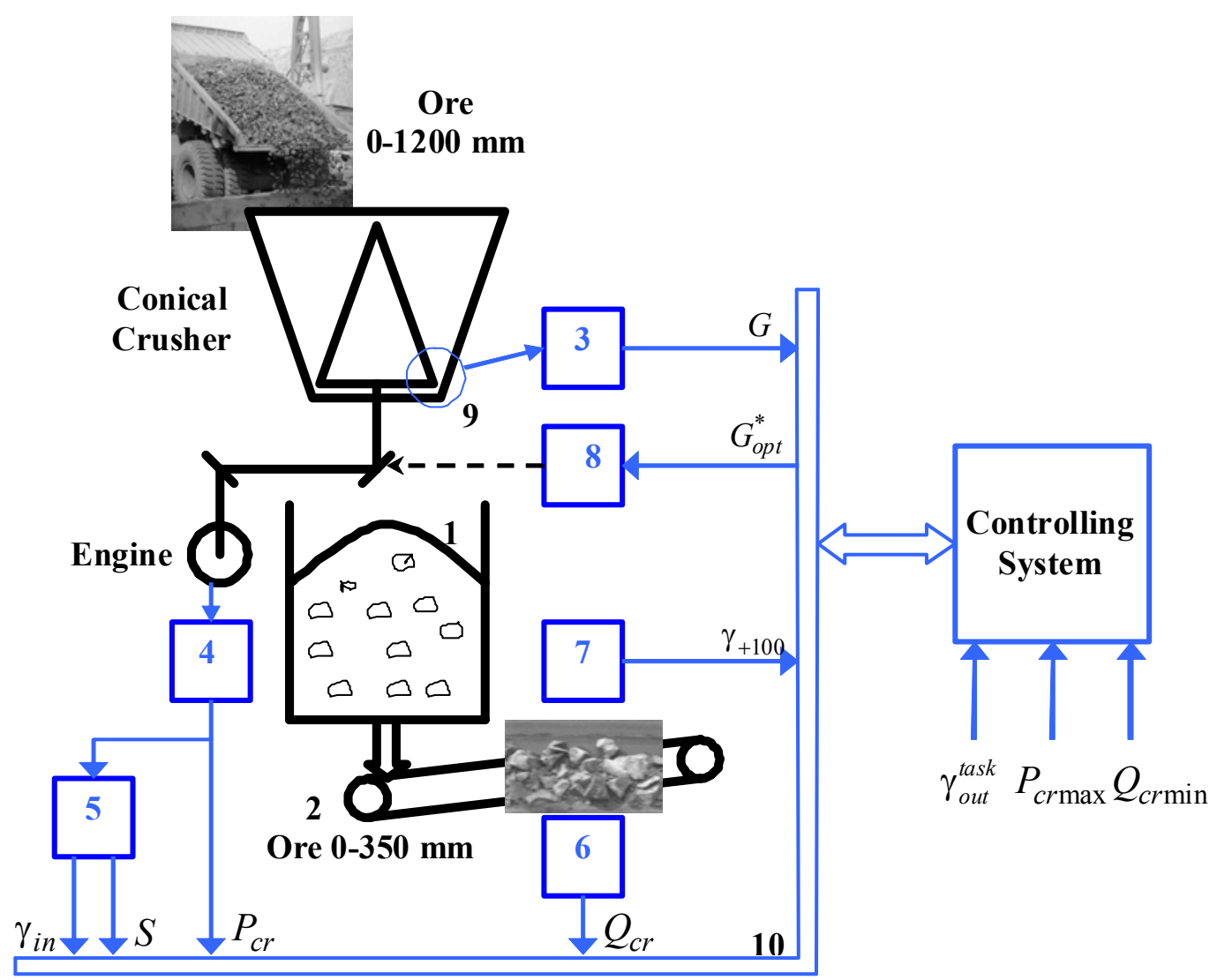

Figure 1 - Scheme of CS of LCP

For simplification of the task solution of optimal control synthesis we will switch from generalized model (6) to the $\mathrm{CO}$ model with linearly entering control by transition from controlling coordinate to its speed (its change for the current control interval) $G^{*}[k]=G[k]-G[k-1]$ :

$$
\vec{\gamma}[k+n]=\vec{A}+\vec{B} \cdot G^{*}[k],
$$

where $\vec{\gamma}[k+n]=\left\{\vec{\gamma}_{\text {out }}[k+n], G[k]\right\}^{T} ; \quad \vec{A}=\left\{F_{\vec{\gamma}}, G[k-1]\right\}^{T}$; $\vec{B}=\{0,1\}^{T}$.

Then taking into account (2), FGW with quadratic functions of control expenses [3] becomes:

$$
\begin{aligned}
& J_{\text {contr }}=E\left\{V\left(\vec{\gamma}\left[k_{j+1}\right]\right)+\sum_{k=k_{j}+n}^{k_{j+1}-1} Q_{z}\left(\vec{\gamma}[k], \gamma_{\text {out }}^{\text {task }}[k]\right)+\right. \\
& \left.+2 \cdot K^{-1} \cdot\left\{\sum_{k=k_{j}}^{k_{j+1}-n-1}\left(G^{*}[k]\right)^{2}+\sum_{k=k_{j}}^{k_{j+1}-n-1}\left(G_{\text {opt }}^{*}[k]\right)^{2}\right\}\right\},(9)
\end{aligned}
$$

where according to (5): $Q_{z}=\left\|\hat{\gamma}_{\text {out }}[k+n]-\gamma_{\text {out }}^{\text {task }}[k+n]\right\|$.

The task consists in finding of value $G^{*}$ opt, which minimizes functional (9) with limitations $P_{c r} \leq P_{c r \max }$, $Q_{c r} \geq Q_{c r \min }$ and $G_{\min } \leq G \leq G_{\max }$.
Bellman discrete equation, taking into consideration the expressions (6), (8)-(9), has the following form:

$$
\begin{gathered}
V_{i}(\vec{\gamma}[i+n])=E\left\{Q_{z}\left(\vec{\gamma}[k], \gamma_{\text {out }}^{\text {task }}[k]\right)+\right. \\
\left.+V_{i+1}\left\{\vec{A}+\vec{B} \cdot G_{\text {opt }}^{*}[i]\right\}-\frac{\partial V_{i+1}}{\partial \vec{\gamma}[i+1]} \cdot \vec{B} \cdot G_{\text {opt }}^{*}[i]\right\} ; \\
i=k_{j+1}-n-1, k_{j+1}-n-2, \ldots, k_{j} .
\end{gathered}
$$

With limiting condition $V_{k_{j+1}}\left(\vec{\gamma}\left[k_{j+1}\right]\right)=V_{z}\left(\vec{\gamma}\left[k_{j+1}\right]\right)$, its solution is determined according to equality $\frac{\partial}{\partial G_{\text {opt }}^{*}}\left(G_{\text {opt }}^{*}[i]\right)^{2}=-\frac{\partial V_{i+1}}{\partial \vec{\gamma}[i+1]} \cdot \vec{B}$ and optimal control is equal to:

$$
G_{o p t}^{*}[i]=-K \cdot \frac{\partial V_{i+1}}{\partial G[i+1]} .
$$

The algorithm of synthesis of the adaptive optimal control includes:

1) estimation of the LCP current state at the moments of beginning of the regular control interval $k_{j}$ according to (7);

2) identification of structure $F_{\widehat{\gamma}}$ and parameters $a_{\hat{\gamma}}$ of the model (6) by the time of $k_{j}$;

3) prediction of LCP free movement in the model (6) (in 
the expanded form (8) with $G^{*}[k]=0$ ) at the current interval $\left[k_{j}+n, k_{j+1}-1\right]$ of control optimization;

4) calculation of gradient of objective function $V_{i+1}(\vec{\gamma}[i+n+1])$ and formation of signal of optimal control according to (10).

The LCP identification consists of the stages of estimation of state and characteristics, as well as structuralparametrical identification [7].

The estimation of state and characteristics of $\mathrm{CO}$ includes the following procedures:

a) determination of $\mathrm{CO}$ functioning mode by Kolmogorov correlation entropy;

b) estimation of CO temporary characteristics (correlation interval of predictability (depth of prediction), equivalent time of delay, period of discretization, correlation dimension of attractor (dimension of phase space - memory depth));

c) formation of estimation of vector of $\mathrm{CO}$ condition $\hat{z}$ according to expression (7).

Structural-parametrical identification of $\mathrm{CO}$ includes:

a) choice of criteria of structural and parametrical identification, basis functions and methods of optimization;

b) structural identification (generation of structures of applicant models and selection of the best of them by criterion of structural optimization);

c) parametrical identification (determination of parameters of model of optimal structure through its training by criterion of regularity).

It is possible to determine the Kolmogorov correlation entropy, which characterizes the estimation of depth of exact prediction of the generating system state and in what mode it is, as well as correlation dimension of attractor (system order) $[11,12]$ by the temporal realizations of the generating process.

When using NN and hybrid NN with fuzzy logic as the basis functions, their parameters are the neurons scales, and coefficients of their functions of activation and membership (for hybrid networks). Their structural characteristics are the type of structure, type of functions of activation and membership, size and quantity of layers, training functions, etc. [7].

The different approaches may be used for determination of $\mathrm{CO}$ model structure. At that, the nonlinear dynamic system (CO model) may be presented by composition of linear dynamic and nonlinear static links, for example, in the form of the Wiener-Hammerstein model [9].

Generally, the criterion of identification (3) is polymodal that demands the use of global optimization methods, among which the most effective are searching methods [13, 14]. There the search algorithm of decision connects the decisions following one after another so that to receive the new best decision.

In algorithms of direct casual search (DCS) the directions are given and the values of criterion $J_{\text {ident }}$ are determined in search points. The development of searching methods is evolutionary algorithms, among which it is most commonly used the genetic algorithms (GA), modeling the development of biological population at genomes level.
For identification it is effective the external criteria, adequate to problem of model creation with minimal dispersion of prediction error, which are divided into criteria of regularity and criteria of unbiasedness [8].

The criterion of regularity (error) is based on division of data into learning $C$ and training $D$ sampling. The model optimization is carried out on learning sampling, and check of its efficiency (error value) on training one. All sampling $N=C+D$.

The criteria of biasing minimum (unbiasedness) are more resistant to disturbances. For example, based on the analysis of decisions the criterion of unbiasedness has the following form:

$$
J_{s m}=\frac{\left\|\hat{\gamma}_{+100 C}[k+n]-\hat{\gamma}_{+100 D}[k+n]\right\|}{\left\|\gamma_{+100}[k+n]\right\|} .
$$

\section{EXPERIMENTS}

When developing the LCP predictive model, as GC of the crushed ore $\gamma_{\text {out }}$ it was used the content of class +100 $\mathrm{mm} \gamma_{+100}$ in it. The experimental values of estimation of the LCP state (7) are determined by results of industrial experiment at the Ingulets Mining and Processing Works. The sample size is $N=60$ time steps (ore portions of dump trucks).

At identification, DCS and GA were applied as global methods of optimization for structure of models of WienerHammerstein with basis functions in the form of NN: cascade, with RBF and Anfis. The criterion of unbiasedness (11) and mean-squared error of the model were used as criteria of structural and parametrical optimization.

The GA had single-point crossing, selective choice of parents and formation of new population with displacement, DCS algorithm - adaptive step of search and complete search around the current iteration. The number of iterations of DCS (in GA of generations) was 100, and size of the DCS search space (in GA population size) - 30 .

The earlier received optimal model was used for estimation of efficiency of LCP CS. The ranges of values of variables were standardized in signals with the range of change $[0,1]$.

The time of admissible downtime of the crushing equipment was used for accounting of restriction on productivity of LCP:

$$
T_{d o p}=T_{n} \cdot\left(Q_{p c}-Q_{p g}\right) / Q_{p g} .
$$

It is taken into account the expenses of time for the scheduled repairs, delays in ore supply and equipment failure in the designed productivity $Q_{p c}$. As long as the setting of optimal change of crushing opening width is performed at its idle running, the time of downtimes because of control realization should be $T_{p r} \leq T_{d o p}$.

The values of $G$ (Control) are structurally limited to values of $G_{\min }=160 \mathrm{~mm}$ and $G_{\max }=240 \mathrm{~mm}, \gamma_{+100}^{\text {task }}=49 \%$ is accepted as the task (Set-point), and the mean-squared deviation (error) of the current content of class $+100 \mathrm{~mm}$ in the crushed ore from the given value is chosen as the quality measure of optimal control. 


\section{RESULTS}

It is determined that for LCP, generating the signal $\gamma_{+100}$, the depth of the exact prediction is 4 time steps, and memory depth - from 3 to 5 time steps.

In result of identification of model structure (fig. 2) it is established that the basis functions in the form of cascade $\mathrm{NN}$ optimized by means of GA are correspond to the minimum of structural criterion of unbiasedness (12). At the same time, the amount of neurons in the hidden layer is 26 , the function of activation of the hidden layer is sigmoid, of the output layer is linear, the NN training algorithm is Fletcher-Reeves method. 0.036 .

The value of the mean-squared error of the LCP model is

The results of LCP modeling in uncontrollable (Plant not control) and managed (Plant with control) modes are given on fig. 3 .
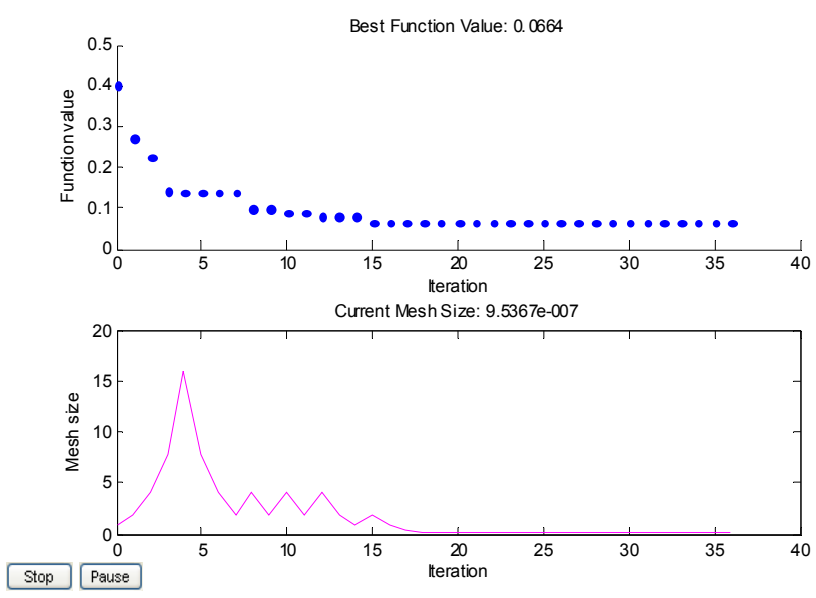

a
The values of the mean-squared deviations of the current content of class $+100 \mathrm{~mm}$ in the crushed ore from the given value are: 0.141 in the uncontrollable mode and 0.076 in controlled mode that determines the decrease of control error in 1.85 time.

\section{DISCUSSION}

The solution of problem of synthesis of LCP optimal control is carried out during system functioning by the principle of minimum of the generalized work on the sliding optimization interval with attraction of information about controlled process state to the new interval of optimization and its future state by the predictive model that allows to simplify the solution of problem of synthesis for nonlinear LCP and to compensate disturbances.

The basis functions in the form of cascade NN correspond to the minimum of test of location for LCP. The models in the form of NN with RBF demand much less calculations, but their value of criterion of unbiasedness is

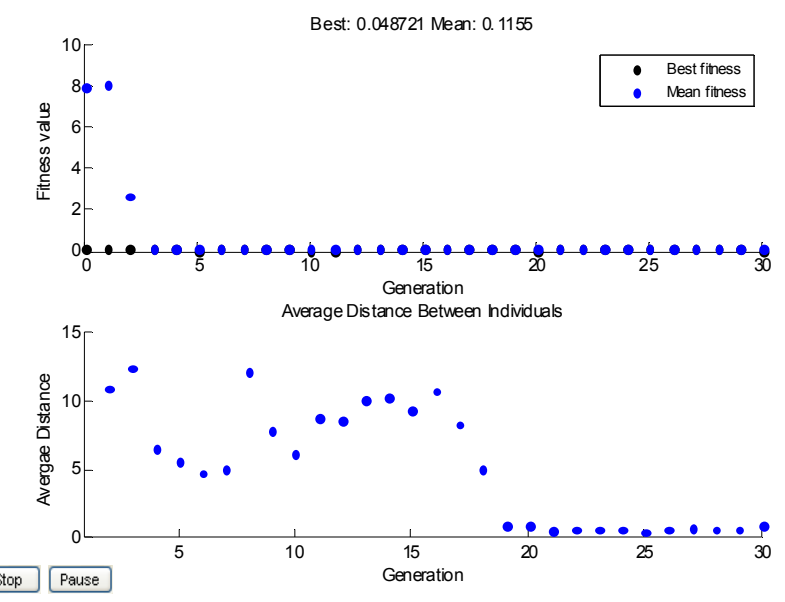

$\mathrm{b}$

Figure 2 - The results of global optimization of the LCP model structure, using DCS $(a)$ and GA $(b)$

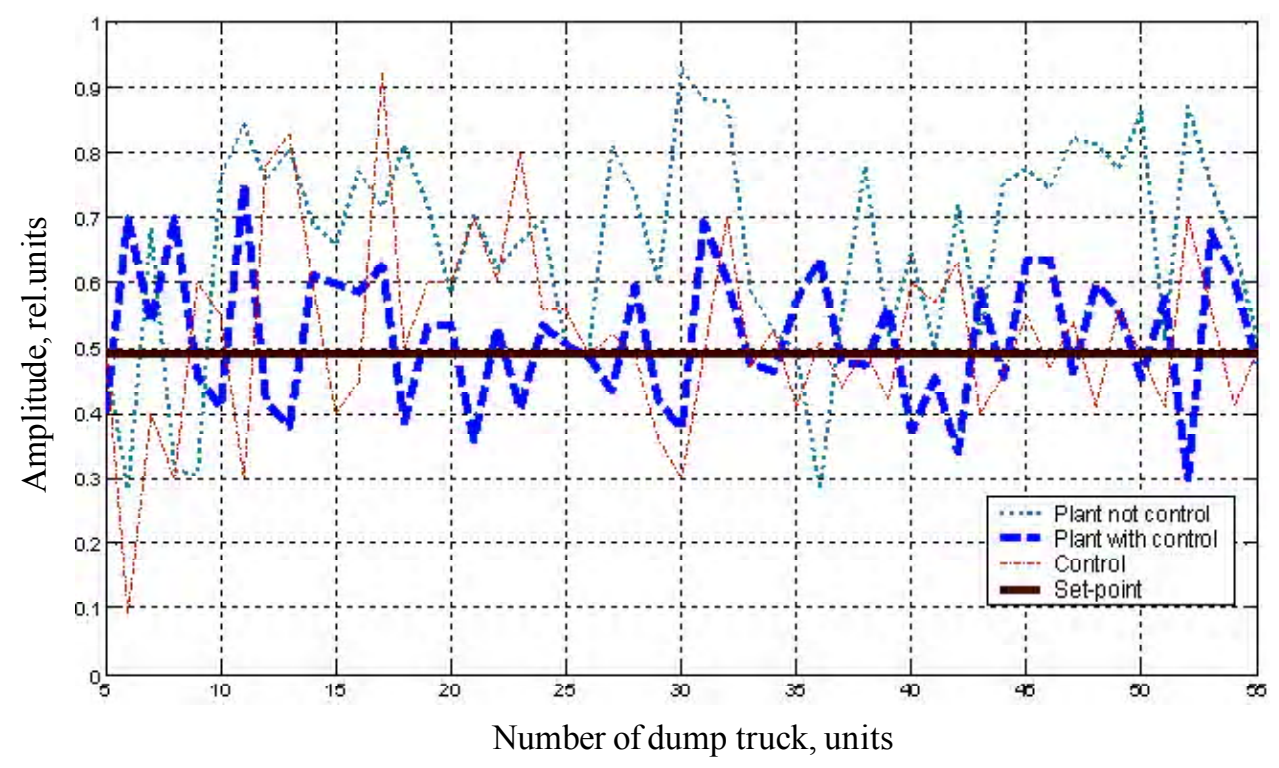

Figure 3 - The results of LCP optimal control 
significantly higher that is possible to explain by poor predictive ability of these NN. The models in the form of NN with fuzzy logic Anfis have sufficient accuracy, but they have low speed at vector lengths of inputs more than 5 (the total quantity of inputs of the LCP model is 10). the higher speed of convergence (GA comes to the area of optimal solutions at the first generations, and DCS - after 15 iterations). The algorithm of DCS revealed the higher speed (4,2 s per iteration with $10,6 \mathrm{~s}$ at generation in GA). The convergence of algorithm of GA is higher than DCS (the values of criterion (11) is 0,048 and 0,066 respectively).

The realization of the offered algorithms does not bring the temporary restrictions to their use in LCP control system.

It is determined that for LCP the offered optimal control with prediction provides the decrease of the control error in $\sim 2$ times and increase of productivity of the process of ore self-grinding, the next one in the technological line, (due to stabilization of content of class $+100 \mathrm{~mm}$ in its input ore) on $3.8 \%$.

The statistical check by nonparametric criterion of signs confirmed the adequacy of the developed LCP model and the importance of the received results.

\section{CONCLUSIONS}

The scientific novelty of the work consists in development of adaptive system of LCP optimal control, in which the optimal control is formed in the course of functioning of CS by the principle of minimum of generalized work with the current estimation of the state of operated process and its future state by the predictive model that provides the CS invariance to the changes of operating modes of the equipment and the disturbing environment, and therefore, the improvement of control quality.

The LCP identification is carried out by definition of the operating mode and dimension of its state, based on which it is performed the model structure and parameters with the help of composition of methods of global and local optimization that allows to increase the model accuracy.

The practical importance of results of the work consists in development of algorithms of the current estimation and prediction of LCP state, its identification and synthesis of optimal control realizing CS. The performed experiments and modeling allowed to estimate the efficiency of the offered solutions.

The further researches should be aimed at design and realization of LCP CS at mining and processing works on iron ores processing.

\section{ACKNOWLEDGEMENTS}

The work is performed within the state budgetary research and development project GP-458 "Intelligent control
In result of modeling (fig. 2), it is established that GA has

technologies of the mining processes in problems of energy saving and energy efficiency" (No. of the state registration 0113U000402) of the State Higher-Education Institution "National Mining University".

\section{REFERENCES}

1. Марюта А. Н. Автоматическое управление технологическими процессами обогатительных фабрик / А. Н. Марюта, Ю. Г. Качан, В. А. Бунько. - М. : Недра, 1983. - 277 с.

2. Optimal Control of Communition Operations / [J. A. Herbst, F. A. Alba, W. T. Pate, A. E. Oblad] // International Journal of Mineral Processing. - 1988. - Vol. 22, № 1-4. - P. 275-296.

3. Справочник по теории автоматического управления / Под ред. А. А. Красовского. - М. : Наука, 1987. - 712 с.

4. Красовский А. А. Универсальные алгоритмы оптимального управления непрерывными процессами / А. А. Красовский, В. Н. Буков, В. С. Шендрик. - М. : Наука, 1977. - 272 с.

5. Kornienko V. I. Methods and principles of control over the complex objects of mining and metallurgical production / V. I. Kornienko, A. Yu. Gusev, A. V. Gerasina // Energy Efficiency Improvement of Geotechnical Systems. - London : CRC Press, Taylor \& Francis Group, 2013. - P. 183-192.

6. Корниенко В. И. Оптимальное управление нелинейным динамическим процессом с интеллектуальным прогнозированием его состояния / В. И. Корниенко, С. М. Мацюк // Штучний інтелект. - 2015. - № 4. - C. 137-145.

7. Method and algorithms of nonlinear dynamic processes identification / [V. I. Korniienko, S. M. Мatsyuк, I. M. Udovik, A. M. Alekseyev] // Науковий вісник Національного гірничого університета. - 2016. - № 1. - С. 98-103.

8. Ивахненко А. Г. Долгосрочное прогнозирование и управление сложными системами / А. Г. Ивахненко. - К. : Техніка, 1975. $-312 \mathrm{c}$.

9. Nelles O. Nonlinear System Identification: From Classical Approaches to Neural and Fuzzy Models / O. Nelles. - Berlin : Springer, 2001. $-785 \mathrm{p}$.

10. Круглов В. В. Нечеткая логика и искусственные нейронные сети / В. В. Круглов, М. И. Дли, Р. Ю. Голунов. - М. : Физматлит, 2001. - 224 с.

11. Шустер Г. Детерминированный хаос. Введение / Г. Шустер. М. : Мир, 1988. - 256 с.

12. Кузнецов С. П. Динамический хаос / С. П. Кузнецов. - М. : Физматлит, 2002. - 296 с.

13. Holland J. H. Adaptation in natural and artificial systems. An introductory analysis with application to biology, control and artificial intelligence / J. H. Holland. - London : Bradford book edition, 1994. - $211 \mathrm{p}$.

14. Генетические алгоритмы, искусственные нейронные сети и проблемы виртуальной реальности / [Г. К. Вороновский, К. В. Махотило, С. Н. Петрашев, С. Н. Сергеев]. - Харьков : Основа, 1997. - 112 с.

Article was submitted 11.07.2017. After revision 20.08.2017.

Корнієнко В. I. ${ }^{1}$, Мацюк С. М. ${ }^{2}$, Удовик I. М.

'Д-р техн. наук, доцент, завідувач кафедри безпеки інформації та телекомунікацій Національного гірничого університета, Дніпро, Україна

${ }^{2}$ Аспірант кафедри безпеки інформації та телекомунікацій Національного гірничого університета, Дніпро, Україна

${ }^{3}$ Канд. техн. наук, доцент, завідувач кафедри програмного забезпечення компьютерных систем Національного гірничого університета, Дніпро, Україна

\section{АДАПТИВНА СИСТЕМА ОПТИМАЛЬНОГО КЕРУВАННЯ ПРОЦЕСОМ КРУПНОГО ДРОБЛЕННЯ РУДИ}

Актуальність. Вирішено завдання підвищення ефективності енергоємного процесу крупного дроблення руди шляхом створення системи оптимального керування ним.

Мета роботи - підвищення якості керування процесом крупного дроблення руди в умовах невизначеності інформації про його стан шляхом синтезу оптимального керування на основі ідентифікації прогнозуючої моделі процесу в ході функціонування системи керування.

Метод. Розроблена адаптивна система оптимального керування процесом крупного дроблення, що реалізовує процедури: оцінки стану керованого процесу, його структурно-параметричної ідентифікації, прогнозування ходу процесу, а також синтезу оптимального 
керування. Рішення задачі синтезу оптимального керування здійснюється в ході функціонування системи за принципом мінімуму узагальненої роботи на ковзному інтервалі оптимізації із залученням інформації про стан керованого процесу до нового інтервалу оптимізації і його майбутнього стану за прогнозуючою моделлю, що дозволяє спростити рішення задачі синтезу для нелінійного процесу крупного дроблення руд і компенсувати збурення. Ідентифікація процесу крупного дроблення руди здійснюється шляхом визначення режиму роботи і розмірності його стану, на основі чого за допомогою композиції методів глобальної і локальної оптимізації визначається структура і параметри прогнозуючої моделі, що дозволяє підвищити ії точність.

Результати. Визначено, що пропоноване оптимальне керування з прогнозуванням забезпечує зниження в $\sim 2$ рази помилки керування і підвищення продуктивності наступного в технологічній лінії процесу самоздрібнювання руди (за рахунок стабілізації вмісту класу +100 мм в його вхідній руді) на $3.8 \%$.

Виводи. Наукова новизна роботи полягає в розробці системи керування процесом крупного дроблення руди, в якій оптимальне керування формується в процесі функціонування системи за принципом мінімуму узагальненої роботи з поточним оцінюванням стану керованого процесу і оцінюванням його майбутнього стану за прогнозуючою моделлю, що забезпечує інваріантність системи керування до змін режимів роботи устаткування та збурюючого середовища, й, таким чином, підвищення якості керування.

Практична значущість результатів роботи полягає в розробці алгоритмів поточного оцінювання і прогнозування стану процесу, його ідентифікації і синтезу оптимального керування, які дозволяють реалізувати систему керування ним.

Ключові слова: крупне дроблення руди, система керування, оптимальне керування, ідентифікація, прогнозування.

Корниенко В. И. ${ }^{1}$, Мацюк С. М. ${ }^{2}$, Удовик И. М. ${ }^{3}$

'Д-р техн. наук, доцент, заведующий кафедры безопасности информации и телекоммуникаций Национального горного университета, Днипро, Украина

${ }^{2}$ Аспирант кафедры безопасности информации и телекоммуникаций Национального горного университета, Днипро, Украина

${ }^{3}$ Канд. техн. наук, доцент, заведующий кафедры программного обеспечения компьютерных систем Национального горного университета, Днипро, Украина

АДАПТИВНАЯ СИСТЕМА ОПТИМАЛЬНОГО УПРАВЛЕНИЯ ПРОЦЕССОМ КРУПНОГО ДРОБЛЕНИЯ РУДЫ

Актуальность. Решена задача повышения эффективности энергоемкого процесса крупного дробления руды путем создания системы оптимального управления ним.

Цель роботы - повышение качества управления процессом крупного дробления руды в условиях неопределенности нформации о его состоянии путем синтеза оптимального управления на основе идентификации прогнозирующей модели процесса в ходе функционирования системы управления.

Метод. Разработана адаптивная система оптимального управления процессом крупного дробления, реализующая процедуры: оценки состояния управляемого процесса, его структурно-параметрической идентификации, прогнозирования хода процесса, а также синтеза оптимального управления. Решение задачи синтеза оптимального управления осуществляется в ходе функционирования системы по принципу минимума обобщенной работы на скользящем интервале оптимизации с привлечением информации о состоянии управляемого процесса к новому интервалу оптимизации и его будущего состояния по прогнозирующей модели, что позволяет упростить решение задачи синтеза для нелинейного процесса крупного дробления руд и компенсировать возмущения. Идентификация процесса крупного дробления руды осуществляется путем определения режима работы и размерности его состояния, на основе чего с помощью композиции методов глобальной и локальной оптимизации определяется структура и параметры прогнозирующей модели, что позволяет повысить ее точность.

Результаты. Определено, что предлагаемое оптимальное управление с прогнозированием обеспечивает снижение в 2 раза ошибки управления и повышение производительности следующего в технологической линии процесса самоизмельчения руды (за счет стабилизации содержания класса +100 мм в его входной руде) на $3.8 \%$.

Выводы. Научная новизна работы состоит в разработке системы управления процессом крупного дробления руды, в которой оптимальное управление формируется в процессе функционирования системы по принципу минимума обощенной работы с текущим оцениванием состояния управляемого процесса и оцениванием его будущего состояния по прогнозирующей модели, что обеспечивает инвариантность системы управления к изменениям режимов работы оборудования и возмущающей среды, и, таким образом, повышение качества управления.

Практическая значимость результатов работы заключается в разработке алгоритмов текущего оценивания и прогнозирования состояния процесса, его идентификации и синтеза оптимального управления, позволяющих реализовать систему управления ним.

Ключевые слова: крупное дробление руды, система управления, оптимальное управление, идентификация, прогнозирование.

\section{REFERENCES}

1. Maryuta A. N., Kachan Yu. G., Bunko BV. A. Avtomaticheskoe upravlenie technologicheskimi protsessami obogatitelnych fabrik. Moscow, Nedra, 1983, 277 p.

2. Herbst J. A., Alba F. A., Pate W. T., Oblad A. E. Optimal Control of Communition Operations, International Journal of Mineral Processing, 1988, Vol. 22, No. 1-4, pp. 275-296.

3. Krasovskogo A. A. pod red. Spravochnik po teorii avtomaticheskogo upravleniya. Moscow, Nauka, 1987, $712 \mathrm{p}$.

4. Krasovskiy A. A., Bukov V. N., Shendrik V. S. Universalnye algoritmy optimalnogo upravleniya nepreryvnymi protsessami. Moscow, Nauka, 1977, 272 p.

5. Kornienko V. I., Gusev A. Yu., Gerasina A. V., Kornienko V. I. Methods and principles of control over the complex objects of mining and metallurgical production, Energy Efficiency Improvement of Geotechnical Systems. London, CRC Press, Taylor \& Francis Group, 2013, pp. 183-192.

6. Kornienko V. I., Matsyuk S. M. Optimalnoe upravlenie nelinejnym dinamicheskim protsessom $\mathrm{s}$ intellektualnym prognozirovaniem ego sostoyaniya, Shtuchnyi intellekt, 2015, No. 4, pp. 137-145.
7. Korniienko V. I., Matsyuк S. M., Udovik I. M., Alekseyev A. M. Method and algorithms of nonlinear dynamic processes identification, Naukovyi visnyk Natsionalnogo girnychogo universyteta, 2016, No. 1, pp. 98-103.

8. Ivachnenko A. G. Dolgosrochnoe prognozirovanie I upravlenie clozhnymi sistemami. Kyiv, Technika, 1975, $312 \mathrm{p}$.

9. Nelles O. Nonlinear System Identification: From Classical Approaches to Neural and Fuzzy Models. Berli. Springer, 2001, $785 \mathrm{p}$.

10.Kruglov V. V., Вдш M. I., Golunov K. Yu. Nrchetkaya logika I isskustvennye nejronnye seti. Moscow, Fizmatlit, 2001, 224 p.

11. Shuster G. Determinirovannyi khaos. Vvedenie. Moscow, Mir, 1988, $256 \mathrm{p}$.

12. Kuznetsov S. P. Dinamicheskiy khaos. Moscow, Fizmatlit, 2002, $296 \mathrm{p}$.

13.Holland J. H. Adaptation in natural and artificial systems. An introductory analysis with application to biology, control and artificial intelligence. London, Bradford book edition, 1994, $211 \mathrm{p}$.

14. Voronovskiy G. K., Makhotilo K. V., Petrashev S. N., Sergeev S. N. Geneticheskie algoritmy, isskustvennye nejronnye seti i problemy virtualnoy realnosti. Kharkov, Osnova, 1997, 112 p. 